\title{
Physocarpus opulifolius (L.) Maxim 'Donna May': A New Compact, Purple-leafed Landscape Shrub
}

\author{
David C. Zlesak ${ }^{1}$ \\ University of Wisconsin-River Falls, 410 S. $3^{\text {rd }}$ Street, River Falls, WI 54022
}

Additional index words. Anthocyanin, inheritance, ninebark

'Donna May' is a new vegetatively propagated cultivar of Physocarpus opulifolius (L.) Maxim (common names include ninebark, common ninebark, and eastern ninebark). 'Donna May' has a compact, well-branched growth habit ( $\approx 1 \mathrm{~m}$ in height and width), purple foliage, powdery mildew resistance, and light pink flowers in mid- to late spring. It is adapted to USDA cold hardiness zones 3 to 7 and does well across a wide range of soil types. The compact, dense growth habit of 'Donna May' offers new versatility for purple purple-leafed ninebark. 'Donna May' can readily be integrated into containers and used in confined landscape beds as a manageable specimen, grouping, and/or hedge.

Physocarpus opulifolius (L.) Maxim is a deciduous woody shrub in the family Rosaceace and subfamily Spiraeoideae. The species is diploid $(2 n=2 x=18)$ and exhibits selfincompatibility (Dickson et al., 1992; Sutherland et al., 2008). Plants typically grow up to $3 \mathrm{~m}$ in height and are native throughout the majority of the eastern half of the United States and Canada with the notable exception of Texas, Louisiana, and Mississippi. Ninebark grows in diverse habitats, including woodland edges, near streams, upland slopes, and rock outcrops (U.S. Department of Agriculture, Natural Resources Conservation Service, 2012). The species is tolerant of variable soil conditions (including a range of soil moisture levels, $\mathrm{pH}$, and textures) and grows well in partial to full sun (Dirr, 2009).

Older stems on maturing plants develop peeling bark that separates in multiple thin layers (inspiring the name ninebark). Leaves are alternately arranged, simple, petiolate, and typically have three to five pronounced, pointed lobes (Dirr, 2009). Five-petaled, typically white flowers last for $\approx 3 \mathrm{~d}$ each and are produced in corymbs in mid- to late spring. Individual flowers open concentrically from the outer edge to the center of corymbs over approximately a 3-week period.

Received for publication 11 July 2012. Accepted for publication 25 July 2012 .

I thank Bailey Nurseries for being a great partner to work with throughout the commercialization of 'Donna May'. 'Donna May' is named in honor of Donna May Zlesak, my mother.

${ }^{1}$ To whom reprint requests should be addressed; e-mail david.zlesak@uwrf.edu.
Eastern ninebark is becoming increasingly popular as a landscape shrub. Greater variation in plant size and leaf color in newer cultivars has especially contributed to its popularity. 'Monlo' (Diabolo ${ }^{\circledR}$, frequently incorrectly spelled Diablo ${ }^{\circledR}$ ) was the first commercialized purple-leafed cultivar. It was discovered as a unique seedling at the German nursery Kordes Jungpflanzen in 1968. 'Monlo' was issued a U.S. Plant Patent in 2000 (U.S. Plant Patent 11,211) and introduced in North America by Monrovia Nursery (Azusa, $\mathrm{CA}$ ). The rich purple foliage and large plant size of 'Monlo' brought eastern ninebark to the forefront as a more densely growing alternative to purple-leafed sand cherry [Prunus $\times$ cistena (N. E. Hansen) Koehne], a predominantly used large purple-leafed shrub. In addition, golden-leafed forms (i.e., 'Luteus' and 'Dart's Gold') and the compact green-leafed 'Nanus' have been landscape staples for decades. Several recent cultivars combine different foliage colors (gold and purple foliage on an individual plant) or foliage colors other than green on more compact plants. Helping to spur on the increase in new cultivars is the fact that purple and gold foliage color in ninebark are simply inherited and easily recovered in progeny. Purple and gold foliage are controlled by different single genes (Pur and Aur located on linkage groups I and III, respectively) and by dominant alleles (Sutherland et al., 2008). Additional reasons for the increased popularity of ninebark is that it is a durable, easy-to-grow U.S. native shrub and can be used as an alternative to purple and yellow-leafed barberry in regions where barberry is deemed invasive (Lubell et al., 2011) or in situations in which the spines of barberry are a liability.

Ninebark is relatively pest-resistant but can be significantly impacted by powdery mildew (Phyllactinia guttata, Podosphaera aphanis var. physocarpi, and Podosphaera macularis) and feeding damage from the specialist ninebark beetle (Calligrapha spiraeae). Lubell et al. (2011) surveyed several popular purple, gold, and green-leafed cultivars of ninebark for powdery mildew resistance. Great variability was found among the cultivars; 'Nanus' was the only cultivar that did not exhibit infection, 'Nugget' had the greatest infection, and 'Monlo' was intermediate. Podosphaera aphanis var. physocarpi only infects ninebark (the others are generalists), and plants infected with this fungal species often display witches' brooms covered in mycelium (i.e., thickened, stunted stem and leaf growth at the terminals). Infected tissue typically dies and becomes unslightly. The generalist fungi typically produce infections more uniformly over plants and do not lead to witches' brooms. The specialist ninebark beetle feeds on the leaves of ninebark. Tenczar and Krischik (2007) compared feeding and reproductive tendencies of the beetle on 'Monlo', 'Dart's Gold', and a wild-type ninebark. They found that the beetles preferred 'Monlo' the least and those forced to feed on only 'Monlo' had the lowest fecundity. They suggest this may be the result of the high anthocyanin content in 'Monlo'. Anthocyanins are known to deter feeding of some insects and bind with nitrogen resulting in a less nutritious food source (Tenczar and Krischik, 2007).

\section{Origin}

A ninebark breeding program was initiated in 2001 in St. Paul, MN (USDA cold hardiness zone 4a; Agricultural Research Service, U.S. Department of Agriculture, 2012), which led to the development of 'Donna May'. The goal of the breeding program was to combine the attractive purple foliage of 'Monlo' (the sole commercialized purpleleafed ninebark at the time) and the compact growth habit of the green-leafed 'Nanus' (nonpatented). Pollinations between 'Monlo' $\times$ 'Nanus' were made in 2001. The resulting seedlings segregated for purple and green foliage and were generally intermediate in growth habit. Segregation of purple vs. green leaves in this population is consistent with the finding of Sutherland et al. (2008) that 'Monlo' is heterozygous for Pur. Genotypes from this population with purple foliage and mildew resistance were retained as parents.

'Donna May' was selected and clonally propagated by stem cuttings during its first growing season in 2005. The maternal parent of 'Donna May' is 2001-1 ('Monlo' × 'Nanus') and the paternal parent is 'Nanus'. The objective of generating the backcross population that led to 'Donna May' was to obtain progeny with purple foliage from 2001-1 and a more compact plant habit and increased powdery mildew resistance from 'Nanus'. The pollination for this population occurred in 2004 and seedlings germinated indoors under lights during the winter of 2004-2005. This backcross population segregated for purple and green leaf color, plant habit, and powdery mildew resistance. Several compact-growing plants with purple foliage were identified and clonally propagated for further trials. 'Donna May' stood out as different from its siblings in that it had the darkest purple foliage and most compact plant habit (Fig. 1). It was also among the seedlings that displayed strong powdery mildew resistance. In subsequent years and vegetative generations, the compact growth habit, purple foliage, and powdery mildew resistance of 'Donna May' proved to be stable. 


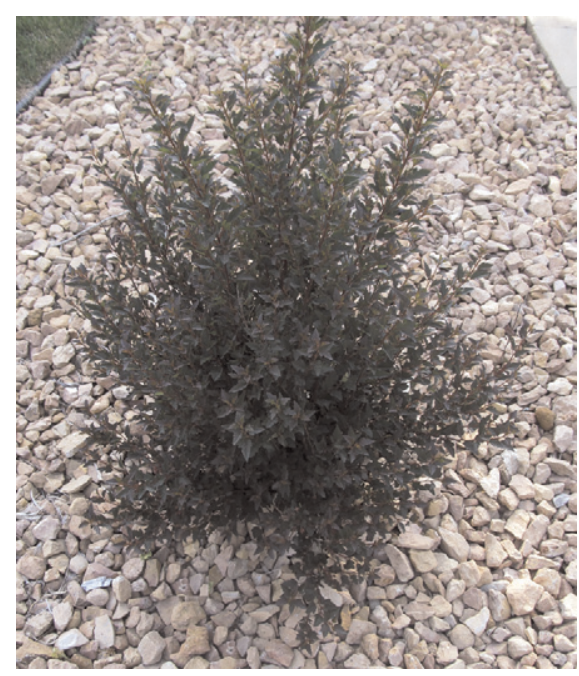

Fig. 1. 'Donna May' eastern ninebark in a St. Paul, MN, landscape July 2012 having been planted from a \#1 nursery container the previous growing season.

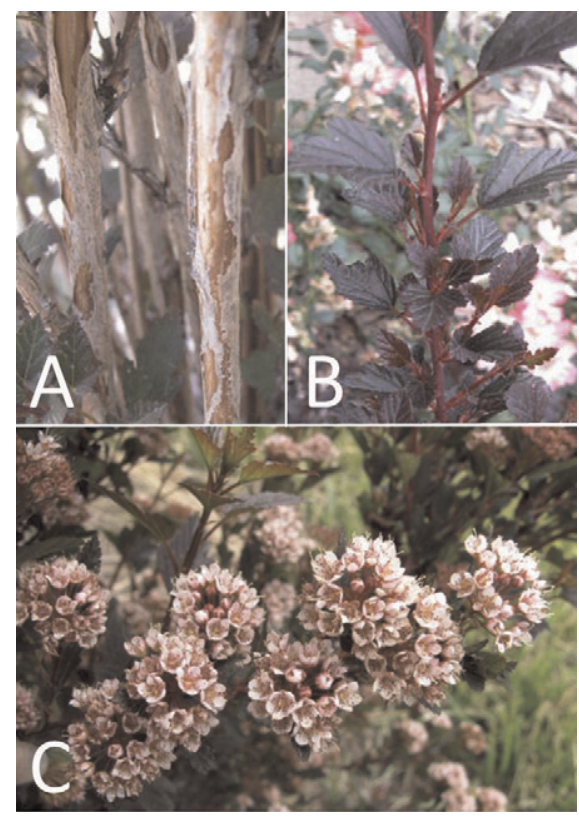

Fig. 2. Key features of 'Donna May' eastern ninebark: (A) peeling bark on maturing stems, (B) branching from axillary buds on current-season growth without pruning, and (C) pink flowers in mid- to late spring.

\section{Description and Performance}

The combination of a dense compact plant habit, small purple foliage, light pink, fivepetaled flowers, and mildew resistance sets 'Donna May' apart from other ninebark cultivars (Figs. 1 and 2). Plants typically grow to between 0.9 and $1.2 \mathrm{~m}$ in height and about the same in width and are well adapted to USDA cold hardiness zones 3 to 7 (feedback has not been received yet from outside these zones). Plant architecture is very similar to 'Nanus' in that there is less apical dominance than other cultivars and wild-type ninebark. Without pruning and in bright light, axillary buds on current season's growth readily develop into new stems (Fig. 2B). This innate branching tendency leads to a relatively dense, rounded, and more self-supporting plant habit, especially when plants are younger. Cultivars with stronger apical dominance and without pruning tend to quickly exhibit a spreading or vase-shaped plant habit from the weight of the vigorous, minimally branched currentseason stems. The dense, initially rounded silhouette of 'Donna May' with no to minimal pruning sets it apart from other popular purple-leafed cultivars.

On 25 May 2012 in the Bailey Nurseries Collections Garden in Cottage Grove, MN, morphological growth measurements were collected on 'Donna May' and seven other ninebark cultivars. Plants in the ninebark collection were well established and planted in the spring of 2010 or before. They were lightly pruned the fall of 2011. Data collected were: internode length, leaf blade length and width, petiole length, flower diameter, and inflorescence diameter. The derived data of leaf blade length:width ratio was calculated. There were 10 replications for each trait per cultivar (except floral data were not collected for 'Nugget' because it had finished blooming by this date). For internode length and flowering traits, each data point was taken from a different stem. Additionally, 10 leaves, one from each of 10 different stems, were used for leaf measurements. For internode length and leaf size traits, data were collected on fully expanded tissue on representative vegetative stems with actively growing, vigorous growing points. 'Donna May' had significantly shorter internodes, smaller leaves, and smaller flowers and inflorescences than the other cultivars, including its recurrent parent 'Nanus' (Table 1; Fig. 3). The leaf blade length:width ratio of 'Donna May' was not significantly different from 'Nanus' but was significantly greater than the other cultivars (Table 1).

The dark-colored foliage of 'Donna May' contrasts nicely with the light pink flowers in mid- to late spring (Fig. 2C). Because blooms are primarily produced on the terminals of short stems from vernalized buds and 'Donna May' is well branched, the floral display of 'Donna May' can be quite showy. During some years, stray flowering during summer at the terminals of current season's growth has been observed. After flowering and with successful fertilization, follicles form. In bright sunlight, the surface of follicles can turn purple to scarlet red in color. In fall the foliage of 'Donna May' typically turns from purple to purple-red. As plants mature, the bark on older stems peels and various colors are visible including white, gray, and tan (Fig. 2A). As a result of the dense plant habit, the attractive bark characteristics are not readily seen until the leaves abscise in fall or one selectively prunes lower branches to make the dominant, older stems more visible.

Leaf color segregation data from progeny of 'Donna May' are consistent with 'Donna May' being heterozygous for the Pur gene as would be expected from its pedigree. 'Donna May' and its compact purple-leafed siblings were allowed to intermate in isolation in 2007 (ninebark is self-incompatible; Sutherland et al., 2008). The segregation data for purple vs. green offspring from the bulked seed collected off of these plants fit the expected 3:1 ratio for offspring from parents heterozygous for Pur (Table 2). In addition, 'Donna May' was crossed as the maternal parent with the golden-leafed 'Nugget' with the goal of generating compact, mildewresistant seedlings with either gold foliage or gold and purple foliage. The segregation data of this controlled cross fit the expected 1:1 purple:green or gold ratio and further confirm 'Donna May' is heterozygous for Pur (Table 2).

'Donna May' has displayed resistance to generalized powdery mildew infection over the plant canopy. Adjacent siblings were covered with generalized infections, but 'Donna

Table 1. Comparison of 'Donna May' with seven other eastern ninebark cultivars for leaf color, internode length, and leaf and flower size parameters

\begin{tabular}{|c|c|c|c|c|c|c|c|c|}
\hline $\begin{array}{c}\text { Cultivar } \\
\text { (trademark) }\end{array}$ & Leaf color & $\begin{array}{c}\text { Internode } \\
\text { length }(\mathrm{cm})\end{array}$ & $\begin{array}{l}\text { Leaf blade } \\
\text { length }(\mathrm{cm})\end{array}$ & $\begin{array}{l}\text { Leaf blade } \\
\text { width }(\mathrm{cm})\end{array}$ & $\begin{array}{l}\text { Leaf blade length/ } \\
\text { width ratio }\end{array}$ & $\begin{array}{c}\text { Petiole } \\
\text { length }(\mathrm{cm})\end{array}$ & $\begin{array}{c}\text { Flower } \\
\text { diam }(\mathrm{cm})\end{array}$ & $\begin{array}{c}\text { Inflorescence } \\
\text { diam }(\mathrm{cm})\end{array}$ \\
\hline Center Glow & Gold and purple & $3.17(0.32) \mathrm{c}^{\mathrm{z}}$ & $7.05(0.59) \mathrm{cd}$ & $5.89(0.65) \mathrm{c}$ & $1.20(0.11) \mathrm{bcd}$ & $1.89(0.24) \mathrm{bc}$ & $1.05(0.07) \mathrm{d}$ & $3.87(0.38) \mathrm{c}$ \\
\hline Dart's Gold & Gold & $2.94(0.72) b c$ & $7.45(1.06) \mathrm{d}$ & $5.67(0.73) \mathrm{c}$ & $1.32(0.12) \mathrm{ab}$ & $1.67(0.23) \mathrm{b}$ & $0.80(0.07) \mathrm{c}$ & $2.75(0.41) b$ \\
\hline $\begin{array}{l}\text { Donna May } \\
\left.\quad \text { (Little Devil }^{\mathrm{TM}}\right)\end{array}$ & Purple & $1.49(0.12) \mathrm{a}$ & $2.82(0.29) \mathrm{a}$ & $2.00(0.15) \mathrm{a}$ & $1.41(0.12) \mathrm{a}$ & $1.05(0.05) \mathrm{a}$ & $0.57(0.07) \mathrm{a}$ & $2.01(0.23) \mathrm{a}$ \\
\hline Monlo (Diabolo ${ }^{\circledR}$ ) & Purple & $4.54(0.77) \mathrm{e}$ & $6.10(0.51) \mathrm{c}$ & $5.75(0.43) \mathrm{c}$ & $1.06(0.08) \mathrm{d}$ & $2.06(0.17) b c$ & $1.01(0.06) \mathrm{d}$ & $4.24(0.41) \mathrm{cd}$ \\
\hline Nanus & Green & $2.29(0.25) b$ & $4.24(0.37) b$ & $3.27(0.32) b$ & $1.30(0.05) \mathrm{abc}$ & $1.94(0.31) b c$ & $0.67(0.07) \mathrm{b}$ & $2.75(0.46) b$ \\
\hline Nugget $^{\mathrm{y}}$ & Gold & $3.21(0.42) \mathrm{cd}$ & $6.82(0.77) \mathrm{cd}$ & $6.03(1.06) \mathrm{c}$ & $1.15(0.11) \mathrm{d}$ & $2.04(0.42) b c$ & & \\
\hline Snowfall & Green & $3.88(0.58) \mathrm{de}$ & $7.16(1.73) \mathrm{cd}$ & $6.19(1.18) \mathrm{c}$ & $1.15(0.11) \mathrm{d}$ & $1.77(0.44) b$ & $1.10(0.07) \mathrm{d}$ & $4.65(0.44) \mathrm{d}$ \\
\hline $\begin{array}{l}\text { Seward (Summer } \\
\text { Wine }^{\mathrm{TM}} \text { ) }\end{array}$ & Purple & $3.18(0.46) \mathrm{cd}$ & $6.69(0.73) \mathrm{cd}$ & $5.79(0.87) \mathrm{c}$ & $1.17(0.10) \mathrm{cd}$ & $2.19(0.18) \mathrm{c}$ & $0.87(0.07) \mathrm{c}$ & $3.70(0.50) \mathrm{c}$ \\
\hline
\end{tabular}

${ }^{\mathrm{z}}$ Means (with standard deviations in parentheses) within column followed by the same letter do not differ significantly using Tukey's honestly significant difference $(\mathrm{n}=10$ replications/trait/cultivar; $P=0.05)$.

${ }^{y}$ Floral data were not collected on 'Nugget' because it had already finished blooming on the day of data collection (25 May 2012 ). 


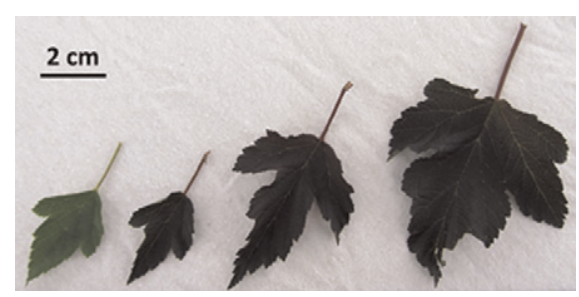

Fig. 3. Representative leaves (left to right) of: Physocarpus opulifolius 'Nanus', 'Donna May' (Little Devil ${ }^{\mathrm{TM}}$ ), 'Seward' (Summer Wine ${ }^{\mathrm{TM}}$ ), and 'Monlo' (Diabolo $\left.{ }^{\circledR}\right)$.

May' was among those uninfected. Infrequent powdery mildew infections leading to sporadic witches' brooms (consistent with Podosphaera aphanis var. physocarpi) have been observed on plants of 'Donna May', similar to what has infrequently been observed on 'Seward' (Summer Wine ${ }^{\mathrm{TM}}$; also a descendent of 'Nanus' and 'Monlo'; personal observation).

\section{Propagation and Production}

'Donna May' is easy to propagate and roots readily from softwood and semihardwood cuttings taken in summer and placed under intermittent mist. Adventitious roots can typically be observed after 3 to 4 weeks under favorable conditions with or without auxin treatments. Salable plants in \#1 nursery containers can be produced within one calendar year, and two calendar years is possible to produce \#2 containers. For best color and growth habit, shrub production protocols using moderate fertilization and moisture levels along with moderate to high light levels are recommended.

Table 2. Segregation of purple: green or gold foliage color in two eastern ninebark populations.

\begin{tabular}{|c|c|c|c|c|c|c|}
\hline \multirow[b]{2}{*}{ Population } & \multicolumn{2}{|c|}{ No. of seedlings } & \multicolumn{3}{|c|}{ Expected purple:green } & \multirow[b]{2}{*}{$P$ value } \\
\hline & Purple & Green or gold & Total & or gold ratio & $\chi^{2}$ & \\
\hline$\overline{\mathrm{BC}_{1} \mathrm{~F}_{2}^{\mathrm{z}}}$ & 122 & 35 & 157 & $3: 1$ & 0.61 & 0.43 \\
\hline 'Donna May' $\times$ 'Nugget' & 41 & 40 & 81 & $1: 1$ & 0.01 & 0.92 \\
\hline
\end{tabular}

${ }^{2}$ The population was developed by allowing the purple-leafed seedlings from the population ('Monlo' $\times$ 'Nanus') $\times$ 'Nanus' $\left(\mathrm{BC}_{1}\right)$ to intermate in isolation $\left(\mathrm{BC}_{1} \mathrm{~F}_{2}\right)$.

\section{Uses}

The compact, dense growth habit of 'Donna May' offers new versatility for purple purple-leafed ninebark. 'Donna May' can readily be integrated into containers and used in confined landscape beds as a manageable specimen, grouping, and/or hedge. As a result of the short internode length, small leaf size, and strong branching tendency, 'Donna May' also responds well to shearing for formal landscape applications. The purple foliage of 'Donna May' provides a nice contrast with especially gold and silver-leafed plants and provides a great backdrop for smaller flowering plants in a wide range of colors.

\section{Availability and Awards}

'Donna May' (U.S. Plant Patent 22,634, Japanese PBR applied for) is sold under the trademark Little Devil ${ }^{\mathrm{TM}}$ within the First Editions ${ }^{\circledR}$ brand. Plants of 'Donna May' are available from Bailey Nurseries (St. Paul, $\mathrm{MN}$ ) and their licensed propagators. It was first sold in limited quantities during the Fall of 2010 with the main commercial launch in Spring 2011. 'Donna May' won multiple awards for being an innovative plant that meets a valuable landscape niche. Awards include: the 2011 Garden Idol award from the American Nursery and Landscape Association, 2011 Best in Category-Hardy Nursery Stock from the Horticultural Trades Association (United Kingdom), 2011 Best New PlantGarden Retail Awards (United Kingdom), and the 2012 Silver Medal at Florall (Belgium).

\section{Literature Cited}

Agricultural Research Service, U.S. Department of Agriculture. 2012. USDA plant hardiness zone map. 11 July 2012. <http://planthardiness.ars. usda.gov>.

Dickson, E.E., K. Arumuganathan, S. Kresovich, and J.J. Doyle. 1992. Nuclear DNA content variation within the rosaceae. Amer. J. Bot. 79:1081-1086.

Dirr, M.A. 2009. Manual of woody landscape plants. $6^{\text {th }}$ Ed. Stipes Publishing, Champaign, IL.

Lubell, J.D., M.H. Brand, and J.M. Lehrer. 2011. Susceptibility of eastern ninebark [Physocarpus opulifolius (L.) Maxim.] cultivars to powdery mildew. J. Environ. Hort. 29:105-107.

Sutherland, B.G., K.R. Tobutt, A. Marchese, G. Paternoster, D.W. Simpson, and D.J. Sargent. 2008. A genetic linkage map of Physocarpus, a member of the Spiraeoideae (Rosaceae), based on RAPD, AFLP, RGA, SSR and gene specific markers. Plant Breed. 127:527-532.

Tenczar, E.G., and V.A. Krischik. 2007. Effects of new cultivars of ninebark on feeding and ovipositional behavior of the specialist ninebark beetle, Calligrapha spiraeae (Coleoptera: Chrysomelidae). HortScience 42:1396-1399.

U.S. Department of Agriculture, Natural Resources Conservation Service. 2012. The PLANTS database. National Plant Data Team, Greensboro, NC. 11 July 2012. <http://plants.usda.gov>. 